\title{
Corruption and long-term investment of businesses in Vietnam
}

\author{
Lai Cao Mai Phuonga ${ }^{\text {* }}$
}

${ }^{a}$ Faculty of Finance and Banking, Industrial University of Ho Chi Minh City, Ho Chi Minh, Vietnam

\begin{tabular}{l}
\hline C H R O N I C L E \\
\hline Article history: \\
Received: June 132020 \\
Received in revised format: June \\
242020 \\
Accepted: June 262020 \\
Available online: \\
June 26 2020 \\
\hline Keywords: \\
Bureaucracy \\
Corruption \\
Revenue \\
Administrative procedures \\
Long-term investment
\end{tabular}

\author{
A B S T R A C T
}

\begin{abstract}
This paper investigates the effects of corruption and long-term investment of businesses in Vietnam using the General Least Square (GLS) estimation method for businesses in 63 provinces in Vietnam from 2016-2018. The results show that corruption was an important factor affecting the long-term investment decisions of Vietnamese enterprises. The ability to predict corruption of businesses can explain the phenomenon of part of the cash flow of businesses flowing out of production and business. Informal costs related to low-level administrative procedures act as "grease" to help businesses reduce time costs, but when the total amount of unofficial expenses exceeds $10 \%$ of revenue of businesses, they become a burden for businesses and restrain them from making long-term investments. Corrupted public officials' behavior has led businesses to misallocate resources and prevent them from making long-term investments. The result shows that the East Asia paradox holds only for the case of informal costs related to administrative procedures in Vietnam.
\end{abstract}

C 2020 by the authors; licensee Growing Science, Canada.

\section{Introduction}

So far, the research on the topic of corruption affecting investment has mainly focused on public finance. Results of previous studies show that corruption increases the cost of public goods (Reinikka \& Svensson, 2004), negatively affecting the performance of investment projects (Egger \& Winner, 2006), reducing domestic investment and the decrease of foreign investment flows (Mauro, 1995). However, there are also studies showing that corruption facilitates business access to resources (Censogor, 2017), reducing time costs (Lui, 1985) thereby improving the quality of investment (Leff, 1964). These studies support Wedeman's "East paradox" view (2003), which states that East Asian countries have high levels of corruption but still retain high growth in the long run. In fact, the number of researches in the direction of corporate finance exploiting the theme of corruption affecting investment is quite small compared to this topic in the field of public finance. In addition, previous studies exploring this topic are often conducted in many countries (Mauro, 1995) but the number of studies in transitioning countries such as Vietnam is very small. Therefore, this article will study the impact of corruption on long-term investment decisions of businesses in Vietnam. 


\section{The impact of corruption on investment}

Corruption reduces investment, leading to economic growth (Mauro, 1995). In particular, bureaucratic efficiency is an important factor determining investment and growth. Mauro (1995) argues that when Bangladesh improves the integrity and efficiency of its bureaucracy to that of Uruguay (less corrupt), its investment rate will increase by nearly five percentage points, and its annual gross domestic product (GDP) growth rate will increase by more than half percentage points. Sharing the same view with Mauro (1995), research on 63 countries between 1970 and 1998 by Méon and Sekkat (2005) shows that corruption reduces the capital accumulation of the economy and thus the negative impact on increasing economic growth. Explaining this phenomenon, Reinikka and Svensson, (2004) suggest that corruption has increased the cost of providing public goods. Surveying public investment projects for primary education in Uganda between 1991-1995, Reinikka and Svensson, (2004) found that schools received only $13 \%$ of the subsidy to pay for non-paying school salaries, most of the school's subsidies have been deprived (captured) by local officials and politicians. At the enterprise level, corruption hinders development by moving resources out of production (Lambsdorff, 2003), leading to inefficient allocation of resources in enterprises (De Jong, Tu, \& Ees, 2012), affecting the performance of investment projects, influencing foreign companies' decision to choose investment destinations and thereby reducing the flow of foreign direct investment (Egger \& Winner, 2006). In addition to studies showing the negative impact of corruption on investment, another view is that corruption facilitates businesses to access resources, information and opportunities higher than actual capacity of their income (Censogor, 2017) so it improves the quality of investment in the case of inefficient government spending (Leff, 1964). The results of Censogor (2017) and Leff (1964) support Wedeman's "East Asia paradox" view (2003). To achieve this benefit, bribes must have an effective investment opportunity, improving the overall investment efficiency. More generally, Leff (1964) argued that corruption is an effective way to select investment projects when those investments depend on obtaining licenses. Moreover, an inefficient bureaucracy constitutes a major obstacle to business operations, so a bribe of money such as "grease" can help businesses overcome this obstacle. Lui (1985) provides an official illustration of this argument and shows that corruption can be an effective way to reduce the time costs of waiting in line. Using data from national surveys before 2011, Huong, Tuyen, Tuan \& Steven (2018) found that corruption has a negative impact on the performance of small and medium enterprises in Vietnam. However, the topic of the impact of corruption on long-term investment by businesses in Vietnam is still relatively small. Therefore, this article will fill this research gap.

\section{Methodology and Data}

\subsection{Methodology}

\section{Research model}

The paper uses an econometric approach to panel data covering businesses in 63 provinces of Vietnam over the period 2016-2018 to examine the impact of corruption on long-term investments of domestic firms. To achieve this goal, a general research model has the form:

\section{$\Delta$ Long-term investment $=\mathrm{F}($ control, corruption $)$}

where:

Dependent variable: The difference between fixed assets and long-term investments (growth rate). The control variables including firm size (SIZE) and firm's business performance (EBTP) are used in the model to ensure that corruption actually affects long-term investment growth in enterprise. Enterprise size (SIZE) is measured by the number of employees of the enterprise having business results. Business performance of the enterprise (EBTP): measured by the proportion of enterprises in the province doing business with profits. Research for small and medium-sized enterprises in Vietnam, Huong et al. (2018) 
suggest that measuring corruption with dummy variables will not see the impact of corruption on firm performance. Therefore, this paper does not use dummy variables but uses four different corruption measures based on Provincial competitiveness index (PCI) survey results from 2016-2018 including:

\begin{tabular}{|c|c|c|}
\hline $\begin{array}{l}\text { Corruption rate in the sector } \\
\text { (c_sector) }\end{array}$ & - & $\begin{array}{l}\text { Percentage of businesses in the province "Agree" to the state- } \\
\text { ment: Enterprises in the same sector often have to pay unof- } \\
\text { ficial expenses. }\end{array}$ \\
\hline $\begin{array}{l}\text { - In which: harassment related } \\
\text { to administrative procedures } \\
\text { for self-seeking. (c_harassed) }\end{array}$ & - & $\begin{array}{l}\text { Percentage of businesses in the province "Agree" to the state- } \\
\text { ment: The situation of harassment when dealing with admin- } \\
\text { istrative procedures for businesses is common. }\end{array}$ \\
\hline $\begin{array}{l}\text { The ability to predict corruption } \\
\text { (c_predict) }\end{array}$ & + & $\begin{array}{l}\text { Percentage of businesses that responded "Always" or "In } \\
\text { most cases" to the statement: The business achieves the ex- } \\
\text { pected results after paying unofficial payments. }\end{array}$ \\
\hline $\begin{array}{l}\text { The burden of corruption in busi- } \\
\text { ness (c_burden) }\end{array}$ & - & $\begin{array}{l}\text { Percentage of businesses in the province that spend more } \\
\text { than } 10 \% \text { of their revenue on informal payments to govern- } \\
\text { ment officials in business-related activities. }\end{array}$ \\
\hline $\begin{array}{l}\text { - In which: Cost of speeding up } \\
\text { is acceptable (c_accept) }\end{array}$ & + & $\begin{array}{l}\text { Percentage of enterprises in the province that answer infor- } \\
\text { mal payments related to general administrative procedures at } \\
\text { an acceptable level. }\end{array}$ \\
\hline
\end{tabular}

Corruption rates in the sector (c_sector) based on the survey question are quite general factors, so in order to better understand the impact of corruption in the sector on long-term investment of enterprises, it is necessary to conduct in-depth research than the manifestations of corruption. To implement this idea, this article focuses on in-depth study of how administrative harassment related to administrative procedures (c_harassed) affects the long-term investment of businesses. The business burden of corruption (c burden) brings together many informal costs that businesses have to pay. Therefore, in addition to measuring the burden of corruption as a proportion of revenue, this article uses unofficial costs related to general administrative procedures (c_accept) to measure the burden of corruption affecting Long-term investment of the business.

\section{Method of estimation:}

A common problem when regressing panel data on financial data are the error terms do not have constant variance and the autocorrelation of residuals. At that time, the General Least Square (GLS) method is often recommended to overcome these problems. Therefore, this article will use the GLS method to estimate on balance panel data.

\subsection{Data}

This paper uses data from 2016-2018 of active domestic enterprises with production and business results. The financial data source of the enterprise is compiled from the white paper 2019 and 2020 published by the Ministry of Planning and Investment and the General Statistics Office.

Observation values of corruption variables are taken from the Provincial Competitiveness Index (PCI) made by the Vietnam Chamber of Commerce and Industry (VCCI) with the support of the United States Agency for International Development (USAID) in Vietnam. The number of domestic enterprises surveyed in the PCI report from 2016 to 2018 were 7,995, 8,292 and 8,681 private enterprises. About 30\% of the businesses surveyed responded each year. 


\section{Results}

\subsection{Statistical analysis:}

\section{Table 1}

The situation of domestic enterprises in Vietnam is operating and producing and trading results

\begin{tabular}{|c|c|c|c|c|c|}
\hline & 2016 & 2017 & 2018 & $\begin{array}{r}\text { Average } \\
2016-2018 \\
\end{array}$ & $\begin{array}{r}\text { Average } \\
2011-2015 \\
\end{array}$ \\
\hline Business number & 505,059 & 560,413 & 610,637 & 558,703 & 377,898 \\
\hline $\begin{array}{l}\text { The number of employees working } \\
\text { in these enterprises (million em- } \\
\text { ployees) }\end{array}$ & 14 & 14.51 & 14.82 & 14.45 & 10.95 \\
\hline $\begin{array}{l}\text { Fixed assets and long-term invest- } \\
\text { ments (trillion VND) }\end{array}$ & 12550 & 13982 & 14108 & 13547 & 7645 \\
\hline Profit before tax (VND trillion) & 711.98 & 877.53 & 895.56 & 828.36 & 159.05 \\
\hline $\begin{array}{l}\text { Proportion of businesses without } \\
\text { losses * }\end{array}$ & $62.12 \%$ & $58.5 \%$ & $54.26 \%$ & $58.29 \%$ & \\
\hline
\end{tabular}

Note: * Calculated by average in 63 provinces of Vietnam.

Source: The White Book on Vietnamese Businesses 2019, 2020 (MOPI, 2019, 2020)

The number of businesses operating in the last 10 years in Vietnam is in an uptrend. On average, in the period of 2016-2018, the number of operating enterprises with production and business results in Vietnam was 558,703 enterprises, an increase of 47.8\% compared to the average period of 2011-2015.

Number of employees working: The number of businesses operating in Vietnam is increasing over the years, leading to the number of employees working in these enterprises is also increasing. On average, in the period of 2016, 2018 enterprises operating with business results in Vietnam attracted 14.45 million employees, an increase of $24.2 \%$ compared to the average period of 2011-2015.

Profit before tax: The total profit before tax of the business sector in 2018 reached 895.56 trillion VND, up $2.1 \%$ compared to the year. On average, in the period of 2016-2018, each year the enterprise was operating, with business and production results generating 828.36 trillion Dong of profit before tax, an increase of $80.8 \%$ compared to the average profit earned in the period of 2011-2015.

Proportion of enterprises without losses: Although the profit before tax of businesses in the period of 2016-2018 in Vietnam is tending to increase, however, the rate of enterprises without losses in 63 provinces of Vietnam in this period is downward trend. The ratio of enterprises with profit and break-even point decreased from $62.12 \%$ (2016) to $54.26 \%$ (2018).

Table 2

Measurement of corruption variables over years

\begin{tabular}{|c|c|c|c|c|c|}
\hline & 2016 & 2017 & 2018 & $\begin{array}{l}\text { Average } 2016- \\
2018\end{array}$ & $\begin{array}{l}\text { Average } 2011- \\
2015\end{array}$ \\
\hline Corruption rate in the sector (c sector) & $64.2 \%$ & $58.3 \%$ & $54.7 \%$ & $59.1 \%$ & $57.3 \%$ \\
\hline $\begin{array}{l}\text { - In which: harassment related to adminis- } \\
\text { trative procedures for self-seeking (c_har- } \\
\text { assed) }\end{array}$ & $58.1 \%$ & $60.1 \%$ & $57.2 \%$ & $58.5 \%$ & $51.1 \%$ \\
\hline $\begin{array}{l}\text { The ability to predict corruption (c pre- } \\
\text { dict) }\end{array}$ & $56 \%$ & $62.8 \%$ & $62.1 \%$ & $60.3 \%$ & $61.1 \%$ \\
\hline $\begin{array}{l}\text { The burden of corruption in business } \\
\text { (c_burden) }\end{array}$ & $10.4 \%$ & $10.5 \%$ & $8.4 \%$ & $9.8 \%$ & $9.2 \%$ \\
\hline $\begin{array}{l}\text { - In which: Cost of speeding up is accepta- } \\
\text { ble (c accept) }\end{array}$ & $78.7 \%$ & $79.4 \%$ & $81.1 \%$ & $79.7 \%$ & $78.2 \% *$ \\
\hline
\end{tabular}


Looking at statistical data shows that the corruption rate in the industry is on a downward trend from 2016-2018. However, this ratio in the period of 2016-2018 is 59.1\%, which is still higher than that of $57.3 \%$ in the period of 2011-2015. In particular, the situation of enterprises being harassed about administrative procedures in business still remained high when increasing from 51.1\% (2011-2015) to 58.5\% (2016-2018). This factor may be one of the causes that negatively impact on production and business activities of enterprises, thereby affecting the long-term investment capital flows of Vietnamese enterprises.

The ability to predict corruption of Vietnamese businesses in 2016-2018 has an average of 60.3\%, down slightly from $61.1 \%$ in 2011-2015. However, in 2017 and 2018, the value of this factor remained high when both reached over $62.1 \%$. This result shows that most businesses think that in order for the job to achieve the expected results, they often have to accept an informal fee.

Burden of corruption: Although the burden of corruption in business in the period of 2016-2018 is tending to decrease, the average value of the burden of corruption in this period is $9.8 \%$ higher than $9,2 \%$ the average of the period 2011-2015. This result may be the cause for the rate of profitable businesses and breakeven in 2016-2018 period which is on a downward trend. The unofficial expense to speed up the progress is acceptable from $78.7 \%$ (2016) to $81.1 \%$ (2018) and the average value in this period is $79.7 \%$ higher than $78,2 \%$ in the period $2013-2015$. This result predicts that businesses are willing to pay informal costs to speed up administrative procedures, and they consider this cost acceptable. In this case, corruption has the effect of overcoming inefficiencies in countries with poor institutions.

When assessing the attractive locations for investment enterprises in the past years, the three major cities in Vietnam took the lead in attracting investment, including Hochiminh City, Danang and Hanoi. The two provinces of Binh Duong and Lao Cai are also in the list of 10 attractive investment locations in Vietnam. Lao Cai is a mountainous area with an unfavorable location due to its distance from major cities but it ranks 6th in the province with favorable business environment and good operating quality. attracting investment. Binh Duong ranks fourth in the lowest investment location in Vietnam, a province highly regarded by the business community in its strong administrative reform efforts. The percentage of enterprises that said "the phenomenon of harassment when dealing with administrative procedures for enterprises in Binh Duong" has decreased significantly from $75 \%$ in 2014 to $52 \%$ in 2016 (PCI Report 2017). The efforts of Binh Duong and Lao Cai have helped these two provinces make the list of attractive provinces to invest in Vietnam.

\subsection{Correlation analysis}

Table 3

Correlation coefficients between pairs of variables

\begin{tabular}{clcccccc}
\hline & size & ebtp & c_sector & c_predict & c_harassed & c_accept & c_burden \\
\hline size & 1.0000 & & & & & & \\
ebtp & -0.4965 & 1.0000 & & & & & \\
c_sector & -0.2024 & -0.0987 & 1.0000 & & & & \\
c_predict & 0.0693 & -0.1644 & 0.5385 & 1.0000 & & & \\
c_harassed & 0.0017 & -0.1581 & 0.6636 & 0.3704 & 1.0000 & & \\
c_accept & 0.0975 & 0.1045 & -0.4589 & -0.3388 & -0.3878 & 1.0000 & \\
c_burden & -0.4684 & 0.2530 & 0.4958 & 0.2373 & 0.2753 & -0.3457 & 1.0000
\end{tabular}

Source: Author calculations based on data collected from VCCI $(2016,2017,2018)$ and MOPI $(2019,2020)$. 
Correlation analysis results show that except for pairs of corrupt measurement variables highly correlated with each other, the remaining pairs have correlation values less than 0.5 . Therefore, to ensure the reliability of the regression results, each corruption variable is regressed along with the control variables according to the general research model. This regression method can determine the effect of corruption on long-term investment of enterprises based on both general factors (c_sector, c_predict, c_burden) and detailed factors (c_harassed, c_accept).

\subsection{Analysis of regression results}

Table 4

Regression results (Dependent variable: $\Delta$ Long-term investment)

\begin{tabular}{|c|c|c|c|c|c|}
\hline Variable & c_sector & c_harassed & c_predict & c_burden & c_accept \\
\hline size & $0.050 * * *$ & $0.030 * * *$ & $0.058 * * *$ & $0.015 * * *$ & $0.031 * * *$ \\
\hline ebtp & $0.006 * * *$ & $0.003 * * *$ & $0.008 * * *$ & $0.003 * * *$ & $0.003 * * *$ \\
\hline c_sector & -0.028 & & & & \\
\hline c_harassed & & $-0.541 * * *$ & & & \\
\hline c_predict & & & $-0.104 *$ & & \\
\hline c_burden & & & & $-0.497 * * *$ & \\
\hline c_accept & & & & & $0.122 * * *$ \\
\hline _cons & $-0.729 * * *$ & -0.014 & $-0.874 * * *$ & $-0.110 * * *$ & $-0.481 * * *$ \\
\hline
\end{tabular}

Source: Author calculations based on data collected from VCCI $(2016,2017,2018)$ and MOPI $(2019,2020)$.

Corruption rate in the industry (c_sector): The regression coefficient of the variable (c_sector) is negative but not statistically significant. This result shows that the corruption rate in the industry is inversely related to the long-term investment of Vietnamese enterprises. However, it cannot explain the impact of corruption on firm's long-term investment based on statistical results. Further research on harassment of civil servants when dealing with administrative procedures of enterprises to benefit interests - an expression of corruption, the coefficient of the variable (c harassed) is less than zero and statistically significant at $1 \%$. This means that when keeping other factors constant, harassment of civil servants related to increased administrative procedures will negatively affect the long-term investment of Vietnamese businesses. This result supports the opinion of De Jong, Tu, \& Ees (2012) when it is argued that corruption leads to misallocation of enterprise resources and negative impact on firm performance in the long run. The ability to predict corruption (c_predict) has a negative regression coefficient and statistically significant shows that businesses in Vietnam think when they accept unofficial payments, the work will achieve results expectations. The higher the proportion of enterprises thinking that way, the higher their likelihood of corruption. Then a part of the cash flow in the business goes out of business, and the capital for long-term investment of Vietnamese enterprises will decrease. In this case, corruption is considered as an expense (Reinikka \& Svensson, 2004) or tax. However, unlike taxes, businesses incur higher costs due to corruption but still bear the risks when they depend on corrupt parties.

The regression coefficient of the business burden of corruption variable (c burden) is negative and statistically significant at $1 \%$. In addition to the variable (c_burden), the paper also assesses the firm's acceptance of informal costs related to general administrative procedures (c_accept). The regression coefficient of the variable (c_accept) is positive and significant $1 \%$ and is on the rise in the period 20162018. This result shows that small costs (such as those related to general administrative procedures) work as "grease" to speed up the process, and a way to reduce the time costs of queuing. waiting (Lui (1985). It supports the idea that corruption has a positive impact on the long-term investment process of 
businesses. However, when the burden of corruption increases, as indicated by the amount of money the enterprise has to spend on informal expenses, which accounts for over $10 \%$ of revenue, corruption will become "sand" in the business wheel of enterprises. In other words, the high burden of corruption (10\% or more of revenue) hinders the long-term investment activities of Vietnamese enterprises (Méon \& Sekkat, 2005).

\section{Conclusions}

In Vietnam, Huong et al (2018) focused on small and medium enterprises in Vietnam and the variable of corruption was only measured in one way. This paper is more extensive than Huong et al. (2018) when corruption is measured in different ways and enterprise data is conducted in a wider range. The paper uses corporate data from the Ministry of Planning and Investment, and a PCI survey report over the years to measure aspects of corruption from 2016-2018 in 63 provinces of Vietnam. The results show that informal costs related to administrative procedures are small, businesses are willing to pay to save transaction time, so this factor has a positive impact on long-term investment of businesses. This result supports the "East Asia paradox" view that corruption is a "grease" for the business wheel of enterprises when the quality of management is not effective. However, when many unofficial expenses combined are greater than $10 \%$ of the enterprise's revenue, it has a negative impact on the long-term investment of businesses in Vietnam. In addition, the frequent acts of corporate harassment and the increased ability to predict corruption are all hindering long-term investments for businesses in Vietnam. Corporate harassment behavior can cause businesses to mis-allocate resources, the higher the ability to predict corruption, the greater the amount of capital flowing out of production and business activities. Accordingly, except for administrative procedures, most aspects of corruption restrain long-term investment of businesses in Vietnam.

The research results show that the role of administrative procedure reform, reducing corruption, improving the quality of governance will create the foundation to attract businesses to invest in the long-term. The fact shows that provinces like Binh Duong and Lao Cai do not have favorable locations like big cities in Vietnam but these two provinces have taken specific actions to create favorable conditions for businesses when they invest. The provinces in Vietnam can refer to the experiences of Binh Duong when implementing administrative procedure reforms in the direction of quick and effective manner, minimizing the phenomenon of corruption and corporate harassment. This has helped businesses save time, reduce costs, thereby contributing to improving the efficiency of the business. Lao Cai's experience in improving operational quality and creating a favorable business environment are also useful lessons for other provinces in Vietnam.

\section{References}

Censogor (2017). Anti-corruption in doing business: an assessment from enterprise perspective. Consultation workshop on two reports surveying practical business integrity experience in Vietnam. Hanoi. $20^{\text {th }}$ Ferbruary 2017.

De Jong, G., Tu, P. A., \& van Ees. H. (2012). Which entrepreneurs bribe and what do they get from it? Exploratory evidence from Vietnam. Entrepreneurship Theory and Practice, 36(2), 323-345.

Huong, V. V., Tuyen, T. Q., Tuan, Ng. V., \& Steven. L. (2018). Corruption. types of corruption and firm financial performance: New evidence from a transitional economy. Journal of Business Ethics, 148(4), 847-858.

Egger, P., \& Winner, H. (2006). How corruption influences foreign direct investment: A panel data study. Economic Development and Cultural Change, 54(2), 459-486.

Lambsdorff, J. G. (2003). How corruption affects productivity. Kyklos, 56(4), 457-474.

Leff, N. H. (1964). Economic development through bureaucratic corruption. American behavioral scientist. 8(3). 8-14.

Lui, F. T. (1985). An equilibrium queuing model of bribery. Journal of Political Economy, 93(4). 760781. 
Mauro, P. (1995). Corruption and growth. The Quarterly Journal of Economics, 110(3), 681-712.

Méon, P. G., \& Sekkat, K. (2005). Does corruption grease or sand the wheels of growth? Public choice, 122(1-2), 69-97.

MOPI (2019). The White Book on Vietnamese Businesses 2019. General Statistics Office of the Ministry of Planning and Investment. Hanoi, Vietnam.

MOPI (2020). The White Book on Vietnamese Businesses 2020. General Statistics Office of the Ministry of Planning and Investment. Hanoi, Vietnam.

Reinikka, R., \& Svensson, J. (2004). Local capture: evidence from a central government transfer program in Uganda. The quarterly journal of economics, 119(2), 679-705.

VCCI (2016). Provincial Competitiveness Index in Vietnam. Hanoi. Vietnam.

VCCI (2017). Provincial Competitiveness Index in Vietnam. Hanoi. Vietnam.

VCCI (2018). Provincial Competitiveness Index in Vietnam. Hanoi. Vietnam.

Wedeman, A. (2003). Development and corruption: The East Asian paradox. In Political Business in East Asia (pp. 50-77). Routledge. https://doi.org/10.4324/9780203166338 chapter_1

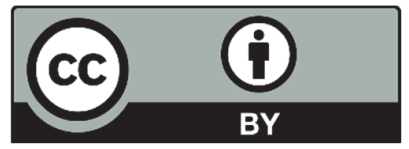

(C) 2020 by the authors; licensee Growing Science, Canada. This is an open access article distributed under the terms and conditions of the Creative Commons Attribution (CCBY) license (http://creativecommons.org/licenses/by/4.0/). 